\title{
RECORDANDO AL DR. VÁCLAV ŠOLC
}

\author{
Luis Alberto Galdames Rosas ${ }^{1}$
}

Cuando el Dr. Calogero Santoro me invitara a participar como comentarista del artículo "Casa aymara en Enquelga", del Dr. Václav Šolc, se despertaron en mí encontrados sentimientos. Finalmente, la tensión se resolvió en favor de la calidez acogedora del recuerdo nostálgico recuperado.

Paso a relatar en breve cómo conocí al Dr. Šolc y el por qué suscitó en mí emociones contrapuestas. Elijo pues este camino y abandono la tarea de comentar derechamente los contenidos del artículo que se ofrece a nuestra consideración.

Hace exactamente 30 años, mientras cursaba los años iniciales de la carrera de Antropología que la Universidad de Chile ofrecía en los recintos del viejo Pedagógico, uno de mis profesores, el Dr. Bernardo Berdichewsky, me efectuó una invitación irresistible.

En efecto, con el propósito de realizar una investigación en terreno, estaba arribando al país el Dr. Václav Šolc, quien le había solicitado a mi profesor de Etnología Americana la colaboración de un ayudante de campo para llevar a cabo trabajo etnográfico en Ollagüe y sus alrededores, al interior de Antofagasta y en la frontera con la República de Bolivia.

El Dr. Šolc solía venir periódicamente a nuestro país, con la finalidad de desarrollar investigaciones tanto en el territorio mapuche como en el aymara.

En esta ocasión, este etnólogo de nacionalidad checoslovaca buscaba determinar el límite sur del poblamiento aymara en el norte de Chile, y su hipótesis era que la Quebrada del Inka, en el sector de Ollagüe, marcaba precisamente dicho límite.

La posibilidad de aprender de tan distinguido científico, cuya obra intelectual curiosamente era poco difundida en Chile, me pareció un privilegio que no pude menos que agradecer a los doctores Berdichewsky y Šolc.

No recuerdo si fue a fines de agosto de 1973 o el primer día de septiembre de ese año, cuando emprendimos vuelo hacia Antofagasta en un avión Ladeco tipo Avro, desde el aeropuerto de Los Cerrillos.
El Dr. Šolc era una persona de mediana estatura, complexión más bien gruesa y pelo cano, de ideas claras y de estilo directo. A poco de vernos, me advirtió: "No soy un buen profesor. Si Ud. desea aprender, tendrá que preguntar". Y así fue aparentemente, pero los múltiples e interminables diálogos (que normalmente eran soliloquios suyos) terminaron por convertirse en verdaderas lecciones magistrales.

Por intermediación de su amigo el Dr. Lautaro Núñez, establecimos contacto con Mr. Barry, el administrador del ferrocarril Antofagasta-La Paz. En un carro privado, de fina factura construido en los albores del siglo pasado, comenzamos a remontar la pampa hasta superar con creces el techo de los 4.000 msm en nuestro destino, la estación ferroviaria de Ollagüe.

Durante varios días recorrimos la Quebrada del Inka, donde se entrevistó a las últimas dos familias que quedaban en el lugar y se realizó, también, un registro acucioso de la cultura material del sitio. Las entrevistas las efectuaba el Dr. Šolc en idioma aymara, una de las catorce lenguas que manejaba.

Por las noches, antes de dormir, el etnólogo checoslovaco dedicaba no menos de dos horas para revisar sus notas y confrontarlas con las mías. En verdad, jamás pude recoger algún dato que él ya no hubiese registrado.

El Dr. Václav Šolc organizaba la recolección de datos y la sistematización de los mismos, acudiendo a la clásica Guía para la clasificación de datos culturales que hacia 1938 escribieran George P. Murdock, Clellan S. Ford y otros.

El uso de esta Guía marcó el estilo de sus trabajos etnográficos, incluyendo por supuesto el artículo que motiva nuestra participación aquí.

La línea central de sus escritos se hallaba presidida por la descripción exhaustiva de los poblados y viviendas, incorporando antecedentes socioculturales de las estructuras de parentesco de los habitantes del sector.

El modo en que se refiere, por ejemplo, a los ceremoniales realizados por los pobladores en la

\footnotetext{
1 Departamento de Ciencias Históricas y Geográficas, Facultad de Educación y Humanidades, Universidad de Tarapacá, Arica, Chile.1galdame@uta.cl
} 
construcción de las estructuras habitacionales y las de culto, jamás pierde sobriedad ni rigurosidad. Practicaba, por así decirlo, una suerte de "realismo objetivo" que le resultaba cómodo y pertinente.

Formaba así parte de esa tradición académica positivista que no miraba con ojos amables la intromisión de lo subjetivo en el proceso de investigación.

Para alcanzar sus propósitos, solía elaborar un riguroso plan de trabajo diario. Nos levantábamos a primera hora para luego efectuar largos recorridos a pie por los senderos y relieves sinuosos de las cajas de los cursos de agua. Pese a sus años, el Dr. Šolc resistía sin esfuerzo el cansancio provocado por el esfuerzo en altura. Aquí debo reconocer otro de sus rasgos personales: jamás una frase crítica o una mirada severa por el evidente cansancio que denunciaba la expresión de mi rostro.

Al llegar las sombras de las noches largas, mientras cenábamos, me insistía en lo vital que era no desperdiciar literalmente ninguna migaja de pan, pues nunca se sabía de las duras sorpresas que la vida podía brindarnos al día siguiente.

El Dr. Šolc bien sabía de lo que hablaba. Las privaciones y riesgos que debió experimentar durante su participación en la Resistencia y en el Levantamiento de Praga durante la ocupación alemana y el posterior periodo de reclusión en un campo de concentración, así se lo demostraron y enseñaron.

Sus heridas existenciales no lo condujeron al ensimismamiento. Fuerte de carácter, como miembro de la Academia de Ciencias de su país y Director del Museo Náprstek de Praga, organizó la red de museos de Viet Nam del Norte y de la República Popular China. Paralelamente, Chile y Bolivia recibieron sus visitas asiduas. En el país altiplánico desarrolló trabajos etnográficos en la provincia Bautista Saavedra; en Chile, en comunidades mapuches del Lago Budi y en poblados aymaras del interior de Iquique.
Su rigurosidad y persistencia eran tales, que mensualmente mantenía correspondencia con los comuneros indígenas, lo que le permitía estar al tanto de lo que con ellos ocurría. Así, al volver a dichos lugares después de un par de años, el tiempo transcurrido no se erigía como obstáculo para reiniciar los vínculos personales.

Al iniciar este relato evocativo, hacía presente que al recibir el artículo del Dr. Šolc experimenté sentimientos encontrados. Aclaro el tema.

Recuerdo que en la tarde del día diez del noveno mes de 1973 recorríamos, vía ferrocarril de carga, las estaciones de Yuma y Ujina. Cuando caía rápida la noche y el frío comenzaba a dominar la puna, la puerta del vagón en que viajábamos fue cerrada por uno de los funcionarios del ferrocarril, procediendo luego a encender una estufa alimentada por llareta.

En la penumbra del recinto, que dejaba adivinar el amarillo pálido del hogar encendido, un silencio pleno de paz acompañó la tibieza amable que hacía recordar, creo, nuestro origen en el vientre materno. Puedo confesar que ha sido el momento en que he experimentado la mayor sensación de paz y plenitud en mi vida.

Finalmente retornamos a Ollagüe. Por la mañana, impulsado por una extraña urgencia, me levanté y, sin desayunar, me dirigí presuroso a las oficinas de la estación, donde los funcionarios ferroviarios poseían un radio receptor. Allí supe que esa mañana del día 11 la historia de mi país y la mía habían comenzado a cambiar radicalmente y para siempre.

El día 12 bajamos a Antofagasta y nunca volví a ver al Dr. Šolc. Al recordarlo hoy, se despiertan también los recuerdos de otra gente, de otros tiempos, de otros sueños, de otro país, evocación que me ha permitido, igualmente, recordar por qué elegí el norte para vivir y desarrollar mi existencia al alero del Ande.

\section{Referencia Citada}

Murdock, G., C. Ford, A. Hudson, R. Kennedy, L. Simmons y J. Whiting

1954 Guía para la Clasificación de los Datos Culturales. Instituto Indigenista Nacional de Guatemala y Oficina de Ciencias Sociales de la Unión Panamericana, México. 